\title{
Four notable additions to the South African echinoid fauna (Echinodermata, Echinoidea)
}

\author{
Zoleka Filander ${ }^{1,2}$, Yves Samyn ${ }^{3}$, Charles Griffiths ${ }^{4}$ \\ I Biodiversity and Coastal Research, Oceans and Coast, Department of Environmental Affairs, Cape Town, \\ South Africa 2 Zoology Department, Nelson Mandela University, Port Elizabeth, South Africa 3 Royal Belgian \\ Institute of Natural Sciences, Brussels, Belgium 4 Marine Research Institute, Department of Biological Sciences, \\ University of Cape Town, Rondebosch 7700, South Africa
}

Corresponding author: Zoleka Filander (zfilander@gmail.com)

Academic editor: A. Martynov | Received 6 November 2018 | Accepted 7 January 2019 | Published 18 March 2019

http://zoobank.org/ADF28EE6-510B-46E8-A131-90DBBEEF403B

Citation: Filander Z, Samyn Y, Griffiths C (2019) Four notable additions to the South African echinoid fauna (Echinodermata, Echinoidea). ZooKeys 831: 71-80. https://doi.org/10.3897/zookeys.831.31381

\begin{abstract}
Although a comprehensive guide to the South African echinoid fauna was published as recently as 2017, four notable additions to the fauna have emerged since that time and are reported on here. The first South African records for Histocidaris purpurata (Thomson, 1872), Echinothrix diadema (Linnaeus, 1758), Microcyphus rousseaui L. Agassiz, in Agassiz and Desor 1846, and Pseudoboletia maculata Troschel, 1869 are presented. All four species have previously been recorded from the Atlantic and/or Indian Oceans and their ranges are thus extended southwards here. These additions increase the total number of echinoid species known from South Africa to 74.
\end{abstract}

\section{Keywords}

Biodiversity, new records, taxonomy

\section{Introduction}

The echinoid fauna of South Africa has recently been revised by Filander and Griffiths (2014), who added 19 species to the regional fauna, and by Filander and Griffiths (2017), who provided an identification key and a guide to each of the 70 species then known from the region. Since the publication of that review, four more remarkable 
additions to the echinoid fauna have been identified and are reported on here. These additions thus increase the number of recorded South African echinoids to 74 species, spread across 29 families.

\section{Materials and methods}

Morphological analysis of the specimens followed the invasive method, which included removal of the primary and secondary spines to expose features of the test. This was done by soaking specimens in a solution of domestic bleach for various time intervals, depending on their size. For the single available specimen of $H$. purpurata the spines were removed from only one half of the test.

Taxa are listed systematically according to Kroh and Smith (2010), which is in line with the classification presented in the World Register of Marine Species (2018), and the scientific name is presented with the author and date of publication. Synonyms are listed in historical order, together with selected literature records under that name. A brief paragraph on the identification features of each species, its previously reported distributional range, and data on the new regional records are also included.

Studied specimens are derived from the following museums:

SAMC Iziko South African Museum, Cape Town, South Africa

RBINS Royal Belgian Institute of Natural Sciences

RMCA Royal Museum for Central Africa, Tervuren, Belgium

\section{Taxonomic part}

Class Echinoidea Leske, 1778

Order Cidaroida Claus, 1880

Family Histocidaroidea Lambert, 1900

Genus Histocidaris Mortensen, 1903

\section{Histocidaris purpurata (Thomson, 1872)}

Fig. 1A, B

Poriocidaris purpurata: Mortensen 1928: 104-107, pl. I, fig. 6, pl. III, figs 3-5 [distribution and synonymy].

Histocidaris purpurata: Clark 1925: 38; Schultz 2011: 872-973, figs.1465-1468; Atkinson et al. 2018: 441.

Identification. Test medium sized (test diameter $=28 \mathrm{~mm}$ ); round and robust. Marginal series with regular and small tubercles. Interambulacra with distinctively large, crenulate primary tubercles. Areoles slightly deepened. Apical system covered with tubercles, ocular plates exsert. Periproct raised, with plates decreasing in size inwards. Primary spines 
cylindrical, tapering gently. Oral spines broad, flattened, slightly curved, with serrated edges. Secondary spines flattened, narrowing towards blunt point. Primary spines brown to purplish violet, with white shaft. Secondary spines light brown. Denuded test white.

Material examined. SAMC.A090123: one specimen collected by an otter trawl through the South African Observation and Environmental Network/Department of Agriculture and Fisheries long-term offshore invertebrate programme in May 2016 on board the Compass Challenger, depth $570 \mathrm{~m}$. Whole specimen preserved in $70 \%$ ethanol.

Habitat. Muddy habitat.

Global distribution. Previously known only from the Atlantic, Ireland to Canary Islands, and the Caribbean, at 750-1084 m depth (Mortensen 1928; Schultz 2011).

South African distribution. South-east coast of South Africa, off Mossel Bay $\left(35.079^{\circ} \mathrm{S}, 23.603^{\circ} \mathrm{E}\right)$.

Remarks. Although Döderlein (1906) previously reported this species in the Indian Ocean (at the Sombrero Channel, Nicobar Islands, at 805 m), Mortensen (1932) disregarded this record on the basis that the specimen was too small and that no adults of this species had been previously collected in the region. The current record therefore represents the first reliable report of this species from the Indian Ocean.

Only one other species, Histocidaris elegans (A. Agassiz, 1879), belonging to this genus has previously been reported in South African waters and this remains a dubious record, as it lacks locality data (Mortensen 1932; Filander and Griffiths 2017). Nonetheless, $H$. purpurata differs from $H$. elegans both in its distinctive coloration and shape of the primary spines. Histocidaris purpurata has a distinctively purple and brown coloration, with thick, cylindrical, and pointed primary spines; whereas $H$. elegans is light brown in colour, with thinner and blunt primary spines.

\section{Order Diadematoida Duncan, 1889 \\ Family Diadematidae Gray, 1855 \\ Genus Echinothrix Peters, 1853}

\section{Echinothrix diadema (Linnaeus, 1758)}

Fig. 1C, D

Garelia cincta: Agassiz 1863: 18-19.

Echinothrix diadema: Mortensen 1940: 290-295, pl. XLIII, figs 1-2, pl. XLV, figs 1-8, pl. XLVI, figs 2-4, pl. XLVII, figs 4, 6-7, pl. XLVIII, fig. 4, pl. LXXI, figs 1, 3 [synonym and description]; Clark and Rowe 1971: 153, fig. 64a [description and distribution]; Samyn and Vanden Berghe 2000: 11 [distribution].

Identification. Test large sized (test diameter $=120 \mathrm{~mm}$ ). Ambulacra not bulging, with one primary tubercle per three pore-pairs. Interambulacra with distinctively large, perforated, and crenulated primary tubercles, where each plate is surrounded by six smaller tubercles. Areoles slightly deepened. Apical system with insert plates, where gonopores are positioned distally on genital plates. Spines banded, long, and needle-like, 
with a ridged surface. Denuded test creamy white and reported by Samyn and Vanden Berghe (2000) to be sometimes reddish.

Material examined. RMCA.2561: one specimen collected from the intertidal zone of Isipingo Beach in August 1999; RMCA.2568: one specimen collected by SCUBA diving off 2-Mile Reef in August 1999, at 15 m. All were complete specimens which were fixed and originally preserved in $90-70 \%$ ethanol. At present they are preserved dry.

Habitat. Littoral and reef habitats.

Global distribution. Indo-Pacific: Paumotu, Tahiti, Hawaii to Japan, north Australia; to Madagascar, East Africa to Red Sea (Mortensen 1940; Clark and Rowe 1971; Samyn and Vanden Berghe 2000).

South African distribution. East coast of South Africa, south of Durban off Isipingo Beach $\left(30.0036^{\circ} \mathrm{S}, 30.9425^{\circ} \mathrm{E}\right.$ : approximate co-ordinates), and off 2-Mile Reef, Sodwana Bay $\left(27.5129^{\circ} \mathrm{S}, 32.6862^{\circ} \mathrm{E}\right.$ : approximate co-ordinates).

Remarks. Echinothrix diadema closely resembles E. calamaris (Pallas, 1774), but differs in coloration, patterns of ambulacra, interambulacra, and apical plates. Echinothrix diadema is not reported to have a greenish denuded test, lacks a conspicuous naked interambulacral space, and the ambulacral tubercles increase in size at the ambitus; the apical plates have numerous tubercles (Mortensen 1940).

The current record was not included in previous South African reviews (Filander and Griffiths 2014; Filander and Griffiths 2017) because these publications were based on Iziko South African Museum samples and online accessible samples. Presented here is new material from the Royal Museum for Central Africa, which was not known by the authors at the time (Filander and Griffiths 2014; Filander and Griffiths 2017).

\section{Order Camarodonta Jackson, 1912}

Family Temnopleuridae A. Agassiz, 1872

Genus Microcyphus L. Agassiz in L. Agassiz \& Desor, 1846

\section{Microcyphus rousseaui L. Agassiz in L. Agassiz \& Desor, 1846}

Fig. 1E, F

Microcyphus rousseaui L. Agassiz \& Desor, 1846: 358, pl. 15.10; Mortensen 1904: 98; Mortensen 1943: 155-159, pl. XIII, figs 18-25, pl. XLVII, figs 18-20, 23-24 [description and synonymy]; Clark and Rowe 1971: 140, 156; Samyn and Vanden Berghe 2000: 6, 13, pl. 1E [distribution]; Schultz 2010: 148, fig. 273 [distribution].

Identification. Test small sized (test diameter $=20 \mathrm{~mm}$ ), low, hemispherical. Ambulacral pore-pairs arranged in double series, outer series formed by pore-pair of median component, and the inner series by pore-pairs of the upper and lower component of each compound ambulacra plate. Interambulacra partially tuberculated, with sparsely and irregularly arranged same-sized tubercles. Naked part of interambulacra broad and conspicuous. Apical system with apical plates densely covered by tubercles, ocular 


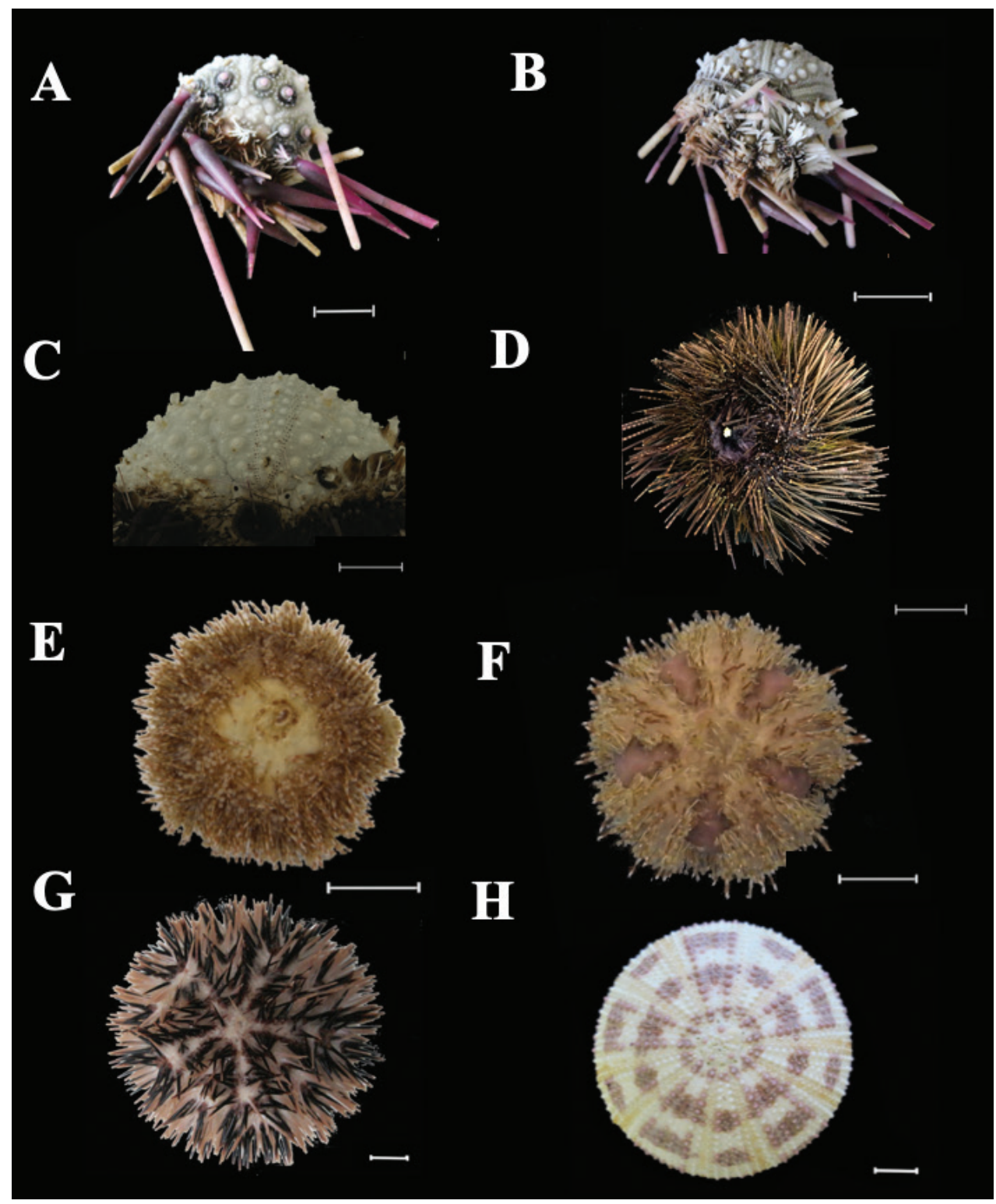

Figure I. A-B (SAMC.A090123, off Mossel Bay): Histocidaris purpurata. A Aboral view of preserved specimen with partially removed spines B Oral view of preserved specimen with partially removed spines C-D Echinothrix diadema C (RMCA.2561, Ispingo). Aboral view of partially denuded test D (RMCA.2568, Sodwana Bay). Oral view of preserved specimen with spines E-F (SAMC. A090124, Sowdana Bay): Microcyphus rousseaui E Oral view of preserved specimen with spines F Aboral view of preserved specimen with spines G-H (SAMC.A090126, Park Rynie): Pseudoboletia maculata $\mathbf{G}$ Aboral view of preserved specimen with spines $\mathbf{H}$ Aboral view of preserved denuded test. Scale bars: $2 \mathrm{~cm}(\mathbf{A}, \mathbf{B}, \mathbf{G}, \mathbf{H}) ; 1 \mathrm{~cm}(\mathbf{C}-\mathbf{F})$. All images were edited in GIMP 2.8.22 by Dr Carl Palmer and plate created by Zoleka Filander. 
plates exsert. Periproct covered with numerous plates. Spines of uniform size, reddishbrown with white tips; naked median areas brownish-red, becoming lighter to centre. Denuded test light brown, with darker tuber-covered parts.

Material examined. SAMC.A090124: two specimens collected by SCUBA diving off Leadsman Shoal, Sodwana Bay; SAMC.A090125: one specimen collected by SCUBA diving off Redsands Reef, Sodwana Bay; RBINS I.G. 33199/Ech.132: one specimen collected by SCUBA diving off the 7-Mile Reef, Sodwana Bay. All samples were collected through the Belgian Global Taxonomy Initiative in January 2016, at a 10-23.9 m depth range. All specimens, except for those belonging to sample SAMC. A090124, are complete with spines and preserved in $70 \%$ ethanol.

Habitat. Reef habitat.

Global distribution. Western Indian Ocean: Red Sea, East African coast southwards to Mozambique (Mortensen 1943; Clark and Rowe 1971; Samyn and Vanden Berghe 2001; Schultz 2010)

South African distribution. East coast of South Africa, off Sodwana Bay; off Leadsman Shoal $\left(27.8737^{\circ} \mathrm{S}, 32.6036^{\circ} \mathrm{E}\right)$, Redsands Reef $\left(27.7384^{\circ} \mathrm{S}, 32.6298^{\circ} \mathrm{E}\right)$, and 7-Mile Reef $\left(27.4515^{\circ} \mathrm{S}, 32.7118^{\circ} \mathrm{E}\right)$.

Remarks. Closely resembles Microcyphus maculatus L. Agassiz in L. Agassiz and Desor 1846 from which it differs in the coloration and apical system. Microcyphus rousseaui has reddish brown spines and apical plates bearing more than three tubercles, whereas $M$. maculata has light green spines and an apical system bearing fewer than three tubercles per plate (Mortensen 1943).

Microcyphus rousseaui differs from M. rousseaui purpuratus Mortensen, 1942 in coloration of the spines, the sub-species having purple spines with distinctive white bands (Mortensen 1942).

This is the first South African record of this species and represents a range extension southwards from Mozambique, the southernmost-recorded location. It is also the first record of the genus in the region.

\section{Family Toxopneustidae Troschel, 1872}

Genus Pseudoboletia Troschel, 1869

\section{Pseudoboletia maculata Troschel, 1869}

Fig. 1G, H

Pseudoboletia maculata Troschel, 1869: 96; Bell 1884: 110, pl. XIII; de Meijere 1904: 286-289, pl. XVII; Clark 1925: 131; Mortensen 1943: 532-534, pl. XLII, figs 4-5, pl. LV, figs 2, 5-6, 16-17, 21 [synonyms and distribution]; Clark and Rowe 1971: 142, 156 [distribution]; Schultz 2010: 264, figs 506-508; Conand et al. 2018: 115 .

Identification. Test large sized $(70 \mathrm{~mm})$ and low, hemispherical in shape. Ambulacra with pore-pairs arranged in a double series per compound plate, with one larger second- 
ary non-crenulated tubercle outside the pore-pair. Interambulacra with sparsely and irregularly arranged same-sized tubercles, which increase in size towards ambitus. Apical system with smooth apical plates encircled by tubercles, ocular plates I and V appear to be insert. Periproct covered with numerous plates. Spines of uniform size, reddish brown and pinkish white. Denuded test white, with dark brown patches on interambulacra.

Material examined. SAMC.A090126: two specimens collected by Roy Jackson from University of KwaZulu-Natal on an intertidal field trip in August 2015. One specimen is preserved as a naked corona and the other is complete with spines. Both specimens are preserved in $70 \%$ ethanol.

Habitat. Rocky shore.

Global distribution. Indo-West Pacific: Ceylon to Australia, 10-100 m depth (Mortensen 1943; Schultz 2010; Arachchige et al. 2017).

South African distribution. East coast of South Africa, off Park Rynie $\left(30.3187^{\circ} \mathrm{S}\right.$, 30.7425 E: approximate co-ordinates).

Remarks. According to our present material, the ocular plates I and V appeared to be insert, which would be consistent with what is observed in other specimens of this species. This is the first South African record, representing a range extension southwards of this species from Madagascar (Clark and Rowe 1971).

\section{Acknowledgements}

The authors are grateful to Dr Lara Atkinson (South African Observation and Environmental Network); and Lindiwe Cele, together with Roy Jackson (University of KwaZulu-Natal) for collecting of the specimens reported here, as well as providing the associated locality data. We would also like to extend our gratitude to Cédric d'Udekem d'Akoz from the Royal Belgian Institute of Natural Sciences for taking an image of Echininothrix diadema (specimen MRAC.2561) for use in this publication. The authors also acknowledge and are grateful to Dr Andreas Kroh from the Natural History Museum in Vienna (Austria) for assisting with some of the literature needed, Dr Carl Palmer from the Alliance for Collaboration on Climate and Earth System Science for editing the images presented here, and to the editor and reviewers who contributed to improving this paper.

\section{References}

Agassiz A (1863) List of the echinoderms sent to different institutions in exchange for other specimens, with annotations. Bulletin of the Museum of Comparative Zoology at Harvard College 1: 17-28.

Agassiz A (1872) Revision of the Echini. Memoirs of the Museum of Comparative Zoology at Harvard College, 378 pp.

Agassiz A (1879) Preliminary report on the Echini of the Exploring Expedition of H.M.S "Challenger”. Proceedings of the American Academy of Arts and Sciences (NS) 6: 190-212. 
Agassiz L, Desor PJE (1846) Catalogue raisonné des familles, des genres, et des espèces de la classe des échinodermes. Annales des Sciences Naturelles, Troisième Série, Zoologie 6, 380 pp.

Arachchige GM, Jayakody S, Mooi R, Kroh A (2017) A review of previous studies on the Sri Lankan echinoid fauna, with an updated species list. Zootaxa 4231: 151-168. https://doi. org/10.11646/zootaxa.4231.2.1

Atkinson L, Mah C, Filander Z, Olbers J, Thandar A (2018) Phylum Echinodermata. In: Atkinson L, Sink K (Eds) Field Guide to the Offshore Marine Invertebrates of South Africa. Malachite Marketing Media, Pretoria, 393-476.

Clark HL (1912) Hawaiian and other Pacific Echini: The Pedinidae, Phymosomatidae, Stomopneustidae, and Echinometridae. Memoirs of the Museum of Comparative Zoology at Harvard College 34(4): 205-383.

Clark HL (1925) A Catalogue of the Recent Sea-urchins (Echinoidea) in the Collection of the British Museum (Natural History). Trustees of the British Museum (Natural History), 250 pp.

Clark AM, Rowe FWE (1971) Monograph of shallow-water Indo-West Pacific echinoderms. Trustees of the British Museum (Natural History), 238 pp.

Claus CFW (1880) Grundzüge der Zoologie ( $4^{\text {th }}$ edn). NG Elwertsche Universitätsbuchhandlung, Marburg \& Leipzig, 821 pp. [vol. 1], 522 pp. [vol. 2]

Conand C, Ribes-Beaudemoulin S, Trentin F, Mulochau T, Boissin E (2018) Marine Biodiversity of La Runion Island: Echinoderms. Western Indian Ocean Journal of Marine Science 17: 111-124.

Döderlein L (1906) Die Echinoiden der deutschen Tiefsee-Expedition. Wissenschaftliche Ergebnisse der Deutschen Tiefsee-Expedition 5(61): 1-290. https://doi.org/10.5962/bhl. title.46999

Duncan PM (1889) A revision of the genera and great groups of the Echinoidea. Journal of the Linnean Society, Zoology 23: 1-311. https://doi.org/10.1111/j.1096-3642.1889.tb01431.x

Filander Z, Griffiths C (2014) Additions to and revision of the South African echinoid fauna (Echinodermata: Echinoidea). African Natural History 10: 47-56.

Filander Z, Griffiths C (2017) Illustrated guide to the echinoid (Echinodermata: Echinoidea) fauna of South Africa. Zootaxa 4296(1): 1-72. https://doi.org/10.11646/zootaxa.4296.1.1

Gray JE (1855) Catalogue of the Recent Echinida, or Sea Eggs: in the Collection of the British Museum. Part I. Echinida Irregularia. Woodfall and Kinder, London, 69 pp.

Jackson R (1912) Phylogeny of the Echini with a revision of Palaeozoic species. Memoirs of the Boston Society of Natural History 7: 1-491. https://doi.org/10.5962/bhl.title.4630

Kroh A, Smith A (2010) The phylogeny and classification of post-Palaeozoic echinoids. Journal of Systematic Palaeontology 8: 147-212. https://doi.org/10.1080/14772011003603556

Lambert J (1900) Étude sur quelques Échinides de l'Infra-Lias et du Lias. Bulletin de la Société des Sciences Historiques et Naturelles de l'Yonne 52: 3-57.

Lambert J (1923) Echinides vivants et fossiles recueillis à Madagascar par M. Raymond Decary. Mémoires de la Société de l'Académie d'Agriculture et des Sciences du Département de l'Aube 85: 13-55.

Leske N (1778) Jacobi Theodori Klein naturalis disposition echinodermatum, edita et descriptionibus novisque inventis et synonomis auctorem aucta. Addimenta ad I. T. Klein naturalem dispositionem Echinodermatum. GE Beer, Leipzig, 278 pp. 
Linnaeus CV (1758) Systema Naturae, edition X, vol. 1 (Systema naturae per regna tria naturae, secundum classes, ordines, genera, species, cum characteribus, differentiis, synonymis, locis. Tomus I. Editio decima, reformata). Holmiae Salvii, 824 pp.

Meijere de J (1904) Die Echinoidea der Siboga-Expedition. Siboga Expeditie 43: 1-252.

Mortensen T (1903) The Danish Ingolf-Expedition 1895-1896. Vol. 4, No. 2. Echinoidea, pt. 1. Bianco Luno, Copenhagen, 198 pp.

Mortensen T (1904) The Danish Expedition to Siam 1899-1900. III. Echinoidea (1). Kongelige Danske Videnskabelige Selskabs, Skrifter, Serie 7, 1/1: 1-124.

Mortensen T (1928) Papers from Dr. Th. Mortensen's Pacific Expedition 1914-16, xliv: New Cidaridae. (Preliminary Notice). Videnskabelige Meddelelser fra Dansk naturhistorisk Forening i Kobenhavn 85: 65-74.

Mortensen T (1932) New contributions to the knowledge of the cidarids. 1. Notes on some recent cidarids (echinoderms, echinoids, taxonomy). Det Kongelige Danske Videnskabernes Selskabs Skrifter 4: 145-174.

Mortensen T (1940) A Monograph of the Echinoidea. III, 1. Aulodonta, with Additions to Vol. II (Lepidocentroida and Stirodonta). CA Reitzel, Copenhagen, $370 \mathrm{pp}$.

Mortensen T (1942) New Echinoidea (Camarodonta). Videnskabelige Meddelelser fra Dansk naturhistorisk Forening i Kobenhavn 106: 225-232.

Mortensen T (1943) A Monograph of the Echinoidea III. 2: Camarodonta. I. Orthopsidae, Glyphocyphidae, Temnopleuridae and Toxopneustidae. CA Reitzel, Copenhagen, 561 pp.

Pallas PS (1774) Spicilegia zoologica, quibus novae imprimis et obscurae animalium species iconibus, Identificationibus atque commentariis illustrantur cura PS Pallas. Fasciculus 10. Prostant apud Gottl. August. Lange, Berolini, 41 pp.

Peters W (1853) Über die an der Küste von Moçambique beobachteten Seeigel und insbesondere über die Gruppe der Diademen. Bericht über die zur Bekanntmachung geeigneten Verhandlungen der Königlichen Preussischen Akademie der Wissenschaften zu Berlin, 1853, 484-465.

Samyn Y, Vanden Berghe W (2000) Annotated checklist of the echinoderms from the Kiunga Marine National Reserve, Kenya - Part I: Echinoidea and Holothuroidea. Journal of East African Natural History 89: 1-34. [2 pls]

Schultz H (2010) Sea-Urchins: A Guide to Worldwide Shallow Water Species. Scientific Publication, Hemdingen, 484 pp.

Schultz H (2011) Sea-Urchins III: Worldwide Regular Deep Water Species. Scientific Publications, Hemdingen, Germany, 861-1338.

Thomson W (1872) On the Echinidea of the 'Porcupine' Deep-sea Dredging Expeditions. Proceedings of the Royal Society of London, 491-497.

Troschel F (1869b) Über einige neue Echiniden. Verhandlungen des Naturhistorischen Vereins Preussens, der Rheinlande, Westphalens und des Regierungs-Bezirks Osnabruck, 26: 96.

Troschel F (1872) Die Familie der echinocidariden (1). Archiv für Naturgeschichte 38: 293-356.

WoRMS Editorial Board (2018) World Register of Marine Species Available from http://www. marinespecies.org at VLIZ. https://doi.org/10.14284/170 [accessed 10 Feb 2018] 


\section{Supplementary material I}

Further additions to the South African echinoid (Echinodermata, Echinoidea) fauna (COL)

Authors: Zoleka Filander, Yves Samyn, Charles Griffiths

Data type: species data

Copyright notice: This dataset is made available under the Open Database License (http://opendatacommons.org/licenses/odbl/1.0/). The Open Database License $(\mathrm{ODbL})$ is a license agreement intended to allow users to freely share, modify, and use this Dataset while maintaining this same freedom for others, provided that the original source and author(s) are credited.

Link: https://doi.org/10.3897/zookeys.831.31381.suppl1 